Валентина Соколовска

Универзитет у Новом Саду

Филозофски факултет
УДК: 316. 022.4: 316.344 .3

Оріинални научни рад

Примљен: 20. 09. 2014

\title{
Исидора Јарић
}

Универзитет у Београду

Филозофски факултет

\section{ОБРАЗОВНО-ЕКОНОМСКИ СТАТУС РОМА У СРБИЈИ И ЊЕГОВА РЕГИОНАЛНА ЗАСТУПЉЕНОСТ ${ }^{1}$}

Сажейак: У раду се йроучава образовна и економска сиирукӣура Рома у Србији. Иситраживане се йемељи на резулйайима йойиса, који су на йерийорији Рейублике Србије сирроведени 2002. и 2011. іодине. Уочене иромене у образовној уйоређују се са ироменама у економској сиирукииури Рома између два йойиса. Сайледава се юихов узрок али и уиичцај на будући йоложај Рома у Србији. У раду се йриказује и рейионална расйодела ове две значајне демоірафске сиирукииуре. Последюи део ииексйа йосвећен је анализи извора средстиава за живой ромске ӣойулације.

Кључне речи: Роми, образовна сіирукӣура, економска стирукӣура, извори средсийава за живой.

\section{Увод}

Ништа ново нећемо рећи ако типичног Рома који живи у Србији опишемо као човека чији је социјални статус неповољан, материјално је угрожен, а културно, образовно и економско маргинализован. Овако се друштвени статус Рома објашњавао још у бившој Југославији (Радушки, 2000-2002, 2003), али и данас. Иако се образовање посматра као кључни фактор социјалне мобилности и друштвене интеграције, низак економски положај и систематско сиромаштво Рома се још увек објашњавају традиционално малим учешћем Рома у образовном систему, што се рефлектује и на економску структуру ромског становни-

1 Чланак је резултат основних истраживања у оквиру пројеката Министарства просвете, науке и технолошког развоја "Изазови нове друштвене интеграције у Србији: концепти и актери“ (179035) и „Значај партиципације у друштвеним мрежама за прилагођавање евроинтеграцијским процесима“" (179037). 
штва (Ђорђевић и остали, 2002, Вујовић, 2008, Радушки, 2009, Товиловић и остали, 2009, Мандић, 2012).

Овакве неповољне почетне позиције одређују ниво ресурса које Роми могу да искористе у савременом друштвеном окружењу. Уколико прихватимо да су ресурси вредне робе у друштву (Granovetter, 1973), чије поседовање појединци одржавају и унапређују ради сопственог интереса, тада на приступ коришћења друштвених ресурса утичу како почетни статус појединаца, тако и јачина и врсте друштвених веза које он може да има (Соколовска, 2011).

По мишљењу неких аутора различитост степена партиципације у различитим нивоима образовања се најлакше може објаснити на основу вредносних ставова различитих група (Ball, 1990). Ипак има утора који сматрају да такав приступ јако подсећа на „окривљавање жртве“ (Tight, 1998), jep за последице утицаја различитих структурних чинилаца и њиховог друштвеног игнорисања оптужује појединца, породицу и вредности друштвене групе.

Како год, када говоримо о проблемима повећања партиципације у образовање припадника одредјених подзаступљених маргинализованих друштвених група јасно је да такав захват захтева озбиљну и далекосежну структурну промену која треба да дође по мишљењу неких аутора управо од самих подзаступљених група (Jones, 2002; Taylor, 2000). Тај пут би подразумевао стварање нове образовне институционалне културе која не би захтевала од ученика да се промене пре него што започну свој образовни пут, у смислу прилагођавања хегемоној образовној култури имагинарне средње класе доминантне етничке заједнице, већ би он требало да створи институционалну културу која перципира диверзитет будућих ученика као одлучну снагу (Thomas, 2002) и нови друштвено-развојни потенцијал који афирмише различитост, охрабрује критичко размишљање, и даје приоритет дају знању које је вредно и релевантно за подзаступљене групе (Freire, 1972), за лични живот људи и које је повезано са персоналним, друштвеним и политичким променама. Оваква нова институционална и образовна култура би требало да обузме машту, охрабри емоционално укључивање и обезбеди задовољавање неиспуњених жеља, и подстакне личне, друштвене и политичке промене (Thompson, 2001, стр. 38).

Циљ овог рада је да, помоћу података пописа обављених 2002. и 2011. године ${ }^{2}$, испита да ли се удео ромског становништва без школске спреме смањује и да ли се образовна структура Рома може довести у везу са регионом у којем

2 Захваљујемо се господину Осману Балићу, председнику ЛИГЕ Рома, који нам је уступио још необјављене податке Републичког завода за статистику Србије о образовној структури и економској активности Рома (попис 2011. године), као и податке о изворима средстава за живот (прикупљене 2010. године). 
Роми живе. Оправданост повезивања образовне структуре и региона проналазимо у резултатима наших ранијих истраживања (Sokolovska, 2012), који показују да учешће становништва без образовања објашњава највећи део разлика међу регионима у Србији. Такође, испитаћемо и јачину повезаности незапослености и броја необразованих Рома, како бисмо објаснили узрок систематског сиромаштва ове мањинске групе. Економску структуру Рома затим посматрамо у регионалном контексту и на крају текста анализирамо изворе средстава за живот ромске популације у Србији.

Када говоримо о школској спреми, регионалној подели једне територије и економској структури, онда у статистичком погледу говоримо о номиналним мерним скалама, које условљавају и метод којим ћемо се надаље служити. Условљени карактеристикама мерења наше закључке изводићемо на основу резултата добијених помоћу две врсти хи-квадрат теста. За мерење разлика у образовној и економској структури Рома на територији Републике Србије између два пописа користили смо хи-квадрат тест прилагођености, док смо везу између региона и образовне структуре Рома испитивали хи-квадрат тестом прилагођености. Код овог теста прикладно је да се покаже, уколико се уочи, и јачина везе. Како се ради о великим табелама контигенције одабрали смо Крамеров коефицијент за мерење јачине асоцијације. За испитивање јачине корелације броја необразованих и незапослених Рома по општинама, користили смо Спирманов тест корелације ранга јер подаци пописа Рома у Србији 2011. години показују висок степен варијабилитета.

\section{1. Промене у образовној структури Рома}

У Републици Србији, на основу пописа 2011. године, живи 13,68\% становништва без школске спреме и са непотпуним основним образовањем, док је учешће Рома у овој категорији становништва 6,38\% (Р3С, 2014). Дакле, скоро половину неписменог становништва Србије чине Роми. Уколико се овим категоријама дода и становништво са завршеном основном школом добијамо $34,43 \%$ становника без стручне квалификације, од чега је 4,11\% Рома. Међутим, уколико резултате овог пописа упоредимо са образовном структуром ромског становништва 2002. године, видећемо колико и у којим правцима су се промене догодиле.

На основу података из табеле 1, емпиријски хи-квадрат тест прилагођености износи 4.543 и већи је од хи-квадрат теста теоријског за 6 степени слободе и нивоом значајности од 0,05 (који износи 12,592), што указује на чињеницу да образовна структура ромског становништва у Републици Србији, између два пописа, бележи статистички значајне разлике. Оне су најуочљивије у колони „без школске спреме и са 1-3 разреда основне школе“ где је смањење од 7,02\%. Овако велика разлика у односу на 2002. годину може се објаснити деловањем 
Валентина Соколовска, Исидора Јарић, Образовно-економски статус Рома у Србији и...

Табела 1. Ромско становништво Републике Србије старо 15 и више година према школској спреми, 2002. и 2011. (\%)

\begin{tabular}{|c|c|c|c|c|c|c|c|}
\hline \multirow[b]{2}{*}{$\begin{array}{l}\text { година } \\
\text { пописа }\end{array}$} & \multicolumn{7}{|c|}{ Школска спрема } \\
\hline & 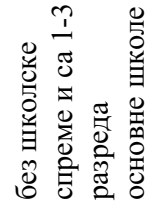 & 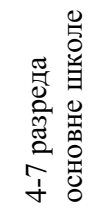 & 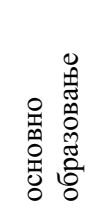 & 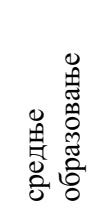 & 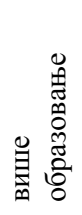 & 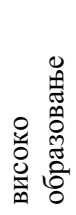 & 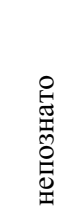 \\
\hline 2002. & 32,45 & 29,42 & 29,01 & 7,81 & 0,20 & 0,11 & 1,00 \\
\hline 2011. & 25,43 & 28,29 & 33,33 & 11,54 & 0,32 & 0,33 & 0,76 \\
\hline
\end{tabular}

неколико чинилаца. Најпре, вишедеценијски низак друштвени положај, условљен и великим удеом необразоване ромске популације, довео је до промене става самих Рома према образовању као формалном каналу друштвени покретљивости. Потом, већа брига државе и многобројних друштвених центара организованих широм Србије посвећена је увођењу маргинализованих друштвених група у образовни систем, што је такође помогло да Роми све више увиде значај образовања за побољшање сопствене економске ситуације. И на крају, не смемо заборавити чињеницу да категорији необразованих у највећем броју припадају најстарији Роми. Тако је кратак животни век Рома такође утицао на смањење удела ромског становништва без школске спреме. Тврдњи да се Роми у све већем броју одлучују да заврше своје школовање говори и чињеница да се удео Рома са завршеном основном школом повећао за 4,32\%, као и удео са завршеним средњим образовањем (за 3,73\%).

Међутим, уочене промене у образовној структури Рома још увек се не утичу значајније на побољшање њиховог друштвеног положаја. Како завршена основна школа не нуди и стручну квалификацију, ово ромско становништво и даље остаје без могућности запослења и сопственог економског збрињавања.

\section{2. Образовна структура Рома и регионална заступљеност}

Да ли се развијеност региона може довести у везу са регионалном поделом једне земље? У уводном делу овог текста оправданост за успостављање овакве релације пронашли смо у нашим ранијим истраживањима, у којима смо показали да становништво без образовања у 64,7\% објашњава различитост региона у Србији (Sokolovska, 2012). У подацима који следе покушаћемо да упоредимо развијеност региона Србије, на основу bruto домаћег производа, са образовном структуром становништва. Након тога, анализираћемо зависност регионалне поделе и школске спреме Рома у 2011. години. 
Прелиминарни резултати обрачуна регионалног bruto домаћег производа Републичког завода за статистику ${ }^{3}$ показују да у 2011. години једино београдски регион бележи његов пораст (индекс нивоа ПС=100 износи 174,6), док региони Шумадије и Западне, као и Источне и Јужне Србије бележе пад (индекси: 68,2 и 64,4). Насупрот њима, у региону Војводине није било промена у односу на претходну годину. Као најразвијенији регион, у Београду живи најмањи број од укупног становништва са завршеном основном школом (15,55\%). Такође, становништво београдског региона карактерише и највећи проценат грађана са завршеним високим образовањем (42,87\%) од укупног високо образованог становништва Србије (РЗС, 2013).

Расподела школске спрема Рома према регионима, приказана у табели 2, је у сагласности са претходним разматрањима и статистички је значајна ${ }^{4}$. Тако у београдском региону живи најмањи проценат Рома без образовања и са незавршеним основним образовањем $(6,98 \%)$ наспрам региона Јужне и Источне Србије у којем тај проценат износи $21,15 \%$.

\section{Табела 2. Ромско становништво Републике Србије старо 15 и више година према школској спреми и регионима, 2011. - табела контигенције (\%)}

\begin{tabular}{|c|c|c|c|c|c|c|c|}
\hline \multirow[b]{2}{*}{ Региони } & \multicolumn{7}{|c|}{ Школска спрема } \\
\hline & 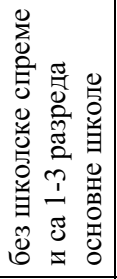 & 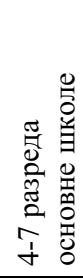 & 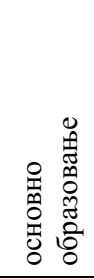 & 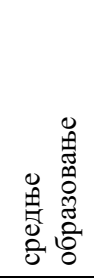 & 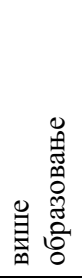 & 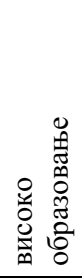 & 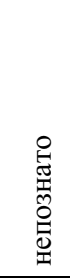 \\
\hline Војводина & 9,02 & 8,80 & 7,79 & 2,59 & 0,05 & 0,06 & 0,08 \\
\hline Београдски регион & 3,87 & 3,11 & 7,90 & 2,55 & 0,07 & 0,07 & 0,25 \\
\hline Шумадија и западна Србија & 3,62 & 4,16 & 4,56 & 1,71 & 0,06 & 0,06 & 0,09 \\
\hline Источна и јужна Србија & 8,93 & 12,22 & 13,08 & 4,68 & 0,14 & 0,13 & 0,35 \\
\hline Укупно & 25,44 & 28,29 & 33,33 & 11,53 & 0,32 & 0,32 & 0,77 \\
\hline
\end{tabular}

3 http://webrzs.stat.gov.rs/WebSite/public/PublicationView.aspx?pKey=41\&pLevel=1\&pubType= 2\&pubKey=2036, web site посећен 08. 10. 2014. године.

${ }^{4}$ На основу података приказаних у табела 2, хи-квадрат тест независности износи 3.030, 238 (за 18 степени слободе, пи вредност<2,2е-16). Међутим, Крамеров коефицијент, којим смо мерили јачину везе између региона и школске спреме показује асоцијацију средњег интензитета (његова вредност је 0,1 ) 
Валентина Соколовска, Исидора Јарић, Образовно-економски статус Рома у Србији и...

\section{3. Економска активност Рома}

Веза између броја необразованих Рома као и оних са незавршеном школском спремом и броја незапослених Рома, у 2011. години, истражена је помоћу Спирмановог коефицијента. Израчуната је јака позитивна корелација између ове две променљиве и она износи 0,912 , при чему висок ниво необразованих Рома прати висок ниво незапослености. Исто тако, број необразованих Рома објашњава $83,17 \%$ варијансе у броју незапослених.

У табели 3 представљени су подаци о економској активности Рома у Републици Србији, прикупљени пописима становништва 2002. и 2011. године. На основу самих разлика учешћа у појединим категоријама може се уочити да је у периоду од 10 година значајно опао проценат запослених Рома и то за 5,95\%, док повећање бележе категорије лица која обављају само кућне послове у свом домаћинству (домаћице) и то за 2,19\%, као и лица из категорије остали за 3,57\%. Ради се о високо статистички значајним разликама, јер је реализовани хи квадрат тест прилагођености (који износи $5.233,6)$ знатно већи од теоријских $(12,6$ за степен слободе 6 и ниво значајности од 5\%, као и 16,8 за исти степен слободе и $1 \%$ нивоа значајности).

\section{Табела 3 Становништво ромске националне припадности према економској активности у Републици Србији ${ }^{5}(\%)$}

\begin{tabular}{|c|c|c|c|c|c|c|c|}
\hline \multirow{3}{*}{$\begin{array}{c}6 \\
\text { Попис }\end{array}$} & \multirow{2}{*}{\multicolumn{2}{|c|}{ Економски активни }} & \multicolumn{4}{|c|}{ Економски неактивни } & \multirow{3}{*}{ 䔅 } \\
\hline & & & \multicolumn{2}{|c|}{$\begin{array}{c}\text { Лица са личним } \\
\text { приходом }\end{array}$} & \multicolumn{2}{|c|}{$\begin{array}{c}\text { Издржавано } \\
\text { становништво }\end{array}$} & \\
\hline & 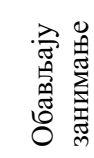 & 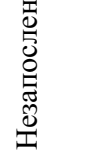 & 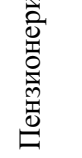 & 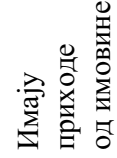 & 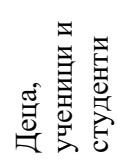 & 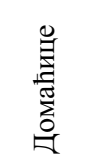 & \\
\hline 2002. & 17,40 & 15,60 & 4,62 & 0,14 & 35,60 & 15,09 & 11,55 \\
\hline 2011. & 11,45 & 16,50 & 4,40 & 0,10 & 35,15 & 17,28 & 15,12 \\
\hline разлике & $-5,95$ & 0,9 & $-0,22$ & $-0,04$ & $-0,45$ & 2,19 & 3,57 \\
\hline
\end{tabular}

${ }^{5}$ У табели нису приказани подаци за лица на раду - боравку у иностранству краћем од 1 године.

${ }^{6}$ Ради поређења резултата два пописа у категорији остало спадају: лица са другим личним приходима (категорија „лица са личним приходом“), као и неспособни за рад и остали који не обављају занимање из категорије „издржавано становништво“. 
У поређењу са економском активношћу Рома у читавој Републици Србији, регион Војводине показује нешто мање смањење запослених Рома (али још увек значајно), повећани број домаћица и лица из категорије остали (табела 4). Разлике уочене између два пописа су и у овом случају високо статистички значајне иако емпиријски хи квадрат тест прилагођености има нешто мању вредност од вредности за целу Србију. Он износи $1.337,2$, док се највеће разлике између емпиријских и теоријских фреквенција виде у категорији запослених Рома, домаћица и осталих. Међутим, његова вредност упућује на закључак о одбацивању нулте хипотезе да распоред фреквенција према категоријама становништва из 2011. године прати распоред структура из 2002. године.

\section{Табела 4. Становништво ромске националне припадности према економској активности у Војводини (\%)}

\begin{tabular}{|c|c|c|c|c|c|c|c|}
\hline \multirow[b]{3}{*}{ Попис } & \multirow{2}{*}{\multicolumn{2}{|c|}{ Економски активни }} & \multicolumn{4}{|c|}{ Економски неактивни } & \multirow[b]{3}{*}{ 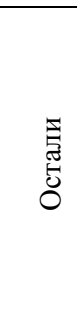 } \\
\hline & & & \multicolumn{2}{|c|}{$\begin{array}{c}\text { Лица са личним } \\
\text { приходом }\end{array}$} & \multicolumn{2}{|c|}{$\begin{array}{l}\text { Издржавано } \\
\text { становништво }\end{array}$} & \\
\hline & 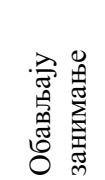 & 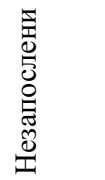 & 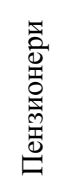 & 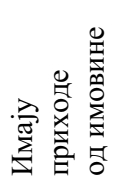 & 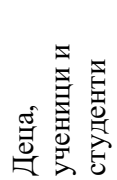 & 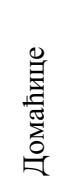 & \\
\hline 2002. & 16,85 & 15,30 & 2,68 & 0,17 & 35,74 & 14,63 & 14,63 \\
\hline 2011. & 11,85 & 13,76 & 2,75 & 0,14 & 35,84 & 18,72 & 16,94 \\
\hline разлике & $-5,00$ & $-1,54$ & 0,07 & $-0,03$ & $-0,10$ & 4,09 & 2,31 \\
\hline
\end{tabular}

За разлику од региона Војводине, у Централној Србији (регион Београда, Шумадија и Западна Србија, као и Источна и Јужна Србија) бележи се највећи пад запослених Рома у односу на попис из 2002. године, али и мањи пораст жена из категорије домаћица (табела 5). Ово повећање је за само 1,43\%, док је у региону Војводине ова категорија порасла за 4,09\%. Такође се уочава да у Војводини опада проценат незапослених лица за 1,54\%, који се 2011. године вероватно налазе у категорији осталих где су лица са другим личним приходима, али и примаоци социјалне помоћи. У Централној Србији ова категорија Рома расте за 1,91\% у односу на попис из 2002. године. Разлике између два пописа, приказане у табели 3 , такође су високо статистички значајне и вредност емпиријског хи квадрат теста прилагођености је много већи у односу на регион Војводине, што указује на веће разлике измећу два пописа забележене у Централној Србији. Он износи 4.423 и такође упућује на закључак да одбацимо нулту хипотезу о једнакости структура између два пописа. 
Валентина Соколовска, Исидора Јарић, Образовно-економски статус Рома у Србији и...

Табела 5. Становништво ромске националне припадности према економској активности у Централној Србији (\%)

\begin{tabular}{|c|c|c|c|c|c|c|c|}
\hline \multirow[b]{3}{*}{ Попис } & \multirow{2}{*}{\multicolumn{2}{|c|}{ Економски активни }} & \multicolumn{4}{|c|}{ Економски неактивни } & \multirow[b]{3}{*}{ Остали } \\
\hline & & & \multicolumn{2}{|c|}{$\begin{array}{c}\text { Лица са личним } \\
\text { приходом }\end{array}$} & \multicolumn{2}{|c|}{$\begin{array}{c}\text { Издржавано } \\
\text { становништво }\end{array}$} & \\
\hline & 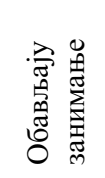 & 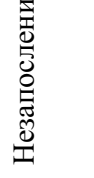 & 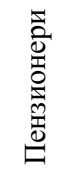 & 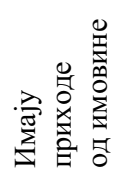 & 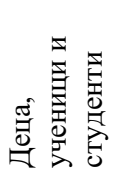 & 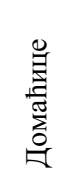 & \\
\hline 2002. & 17,61 & 15,70 & 5,33 & 0,13 & 35,54 & 15,27 & 10,42 \\
\hline 2011. & 11,28 & 17,61 & 5,08 & 0,07 & 34,87 & 16,70 & 14,39 \\
\hline разлике & $-6,33$ & 1,91 & $-0,25$ & $-0,06$ & $-0,67$ & 1,43 & 3,97 \\
\hline
\end{tabular}

\section{4. Регионалне разлике економске активности ромске популације на основу пописа 2011. године}

У табели 6 приказана је економска активност Рома по регионима у 2011. години. Иако је хи квадрат значајан (вредност 330,178 за 3 степена слободе, пи вредност $<2.2 \mathrm{e}-16)$, коефицијент контигенције и Крамеров В, као показатељи јачине асоцијације између региона и економске активности, показују веома слабу везу (износе 0,047$)$. Значајност хи квадрата у овом случају последица је великог узорка, што је потврђено Крамеровим В показатељем, те можемо закључити да између региона и економске (не)активности Рома нема изражене асоцијативности. Другим речима, неоправдано је издвојити било који регион Републике Србије (формиран по НУТС 2 критеријуму) и рећи да у њему живе Роми који су нпр. више запослени или издржавани. Економска структура Рома је дакле равномерно распоређена на читавој територији Србије.

\section{Табела 6. Роми према економској активности и регионима, попис 2011.}

\begin{tabular}{|l|r|r|r|}
\hline Регион & $\begin{array}{c}\text { Економско } \\
\text { активни }\end{array}$ & $\begin{array}{c}\text { Економско } \\
\text { неактивни }\end{array}$ & УКУПНО \\
\hline Војводина & 10.855 & 31.536 & 42.391 \\
\hline Београд & 7.115 & 20.210 & 27.325 \\
\hline Шумадија и Западна Србија & 5.909 & 14.740 & 20.649 \\
\hline Источна и Јужна Србија & 17.358 & 39.881 & 57.239 \\
\hline УКУПНО & 41.237 & 106.367 & 147.604 \\
\hline
\end{tabular}




\section{5. Ромско становништво према изворима средстава за живот у години која је претходила попису 2011. године}

На територији Републике Србије, од укупне популације Рома само је њих $27,95 \%$ економско активно, док 72,05\% Републички завод за статистику Србије убраја у економско неактивне (табела 3). Међутим, према резултатима пописа обављеног 2011. године само је 11,45\% Рома запослено. Наредна табела (табела 7) приказује ромско становништво према изворима за живот у години која је претходила попису 2011. године. ${ }^{7}$ Везу између региона и извора средстава за живот испитали смо, као и у претходном случају, хи квадрат тестом независности. Он у овом случају износи 2584,371 (за 24 степена слободе, пи вредност $<2.2 \mathrm{e}-16$ ) и показује статистичку значајност. Међутим, и у овом случају ради се о утицају величине узорка на његову вредност, а не о показатељу асоцијације (коефицијент контигенције је 0,131 , Крамеров В 0,076$)$, те не можемо говорити да између просторног, регионалног размештаја Рома и изворима средстава за живот постоји зависност.

\section{Табела 7 Ромско становништво према изворима за живот}

\section{у 2010. години, према регионима}

\begin{tabular}{|c|c|c|c|c|c|}
\hline & 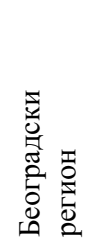 & 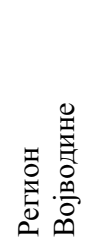 & 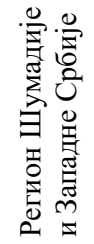 & 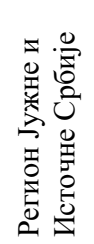 & 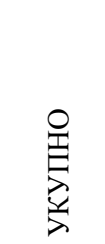 \\
\hline $\begin{array}{l}\text { зарада или друга примања } \\
\text { по основу рада }\end{array}$ & 3937 & 4420 & 2386 & 4999 & 15742 \\
\hline пензија & 1283 & 1115 & 1033 & 2920 & 6351 \\
\hline приходи од имовине & 37 & 95 & 45 & 47 & 224 \\
\hline социјална примања & 2525 & 8728 & 3758 & 10036 & 25047 \\
\hline $\begin{array}{l}\text { ступендија за ученике/студенте, } \\
\text { студентски кредит }\end{array}$ & 9 & 27 & 7 & 34 & 77 \\
\hline зајам, уштеђевина & 37 & 110 & 81 & 192 & 420 \\
\hline новчана накнада за незапослена лица & 75 & 135 & 47 & 143 & 400 \\
\hline издржавана лица & 16633 & 23857 & 11273 & 32396 & 84159 \\
\hline остало & 2789 & 3904 & 2019 & 6472 & 15184 \\
\hline УКУПНО & 27325 & 42391 & 20649 & 57239 & 147604 \\
\hline
\end{tabular}

7 Према методологији прикупљања података Републичког завода за статистику Србије у табели 7 су приказана лица према главном извору прихода, тј. о извору који је био највећи или највреднији током године, али и подаци о свим изворима средстава (сталних или повремених). Такође, табела 7 приказује приходе током 2010. године, док су у претходним табелама (табеле 3-6) 
Валентина Соколовска, Исидора Јарић, Образовно-економски статус Рома у Србији и...

Иако је, у статистичком погледу, веза између региона и извора средстава за живот статистички безначајна, у наредној табели контигенције (табели 8) приказали смо расподелу извора средстава за живот према регионима. На основу ње видимо да регион Јужне и Источне Србије предњачи у запошљавању Рома (3,39\%), одмах потом регион Војводине (3,00\%), док је у остала два региона ово учешће испод $3 \%$. Од укупних средстава за живот, од зарада или других примања на основу рада живи само 10,68\% Рома. Укупно учешће Рома пензионера је веома ниско и оно износи 4,31\% за целу популацију. Ако се погледа ова расподела према регионима, регион Јужне и Источне Србије има највећи проценат пензионера (1,98\%), док остали региони бележе мање од 1\% пензионера.

\section{Табела 8 Ромско становништво према изворима за живот у 2010. години, према регионима (\%)}

\begin{tabular}{|c|c|c|c|c|c|}
\hline & 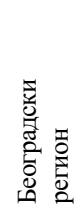 & 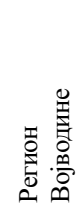 & 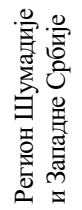 & 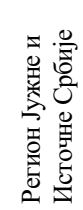 & 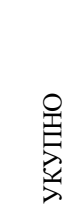 \\
\hline зарада или друга примања по основу рада & 2,67 & 3,00 & 1,62 & 3,39 & 10,68 \\
\hline пензија & 0,87 & 0,76 & 0,70 & 1,98 & 4,31 \\
\hline приходи од имовине & 0,03 & 0,06 & 0,03 & 0,03 & 0,15 \\
\hline социјална примања & 1,71 & 5,91 & 2,55 & 6,80 & 16,97 \\
\hline ступендија за ученике/студенте, студентски кредит & $0,00^{8}$ & 0,02 & $0,00^{9}$ & 0,02 & 0,04 \\
\hline зајам, уштеђевина & 0,03 & 0,07 & 0,05 & 0,13 & 0,28 \\
\hline новчана накнада за незапослена лица & 0,05 & 0,09 & 0,03 & 0,10 & 0,27 \\
\hline издржавана лица & 11,27 & 16,16 & 7,64 & 21,95 & 57,02 \\
\hline остало & 1,89 & 2,64 & 1,37 & 4,38 & 10,28 \\
\hline УКУПНО & 18,52 & 28,71 & 13,99 & 38,78 & 100,00 \\
\hline
\end{tabular}

С друге стране, социјална примања су, осим учешћа издржаваних лица, највеће учешће у укупној структури Рома према изворима средстава за живот. За територију целе Републике Србије овај проценат износи 16,97\%. Уколико узмемо у обзир ниска новчана примања која примаоци социјалне помоћи добијају,

приказани подаци о економској активности Рома у референтној недељи (недељи пред попис) у складу са међународним препорукама. Због тога се у табели 7 могу наћи лица која су током 2010. године радила и навела зараду као главни извор прихода, док су у табелама о економској активности они сврстани као незапослени или пензионери, уколико им се статус променио.

8 Веома мало учешће, јер апсолутна фреквенција износи свега 9 примаоца ученичког/студентског кредита или стипендије.

9 Веома мало учешће, јер апсолутна фреквенција износи свега 7 примаоца ученичког/студентског кредита или стипендије. 
онда ова категорија Рома заједно са запосленим Ромима, пензионерима и веома малим учешћем Рома који имају приход од имовине $(0,15 \%)$, живе од зајма или уштеђевине $(0,28 \%)$, као и оних који примају новчану накнаду за незапослена лица $(0,27 \%)$, издржава више од половине ромске популације на територији Републике Србије. Укупно учешће Рома који припадају категорији издржаваних лица (а то су деца, домаћице и неспособни за рад) износи 57,02\%.

На основу свега реченог, верујемо да ће се у блиској будућности тенденција повећања стеченог нивоа образовања унутар ромске популације уочена у последњих десет година наставити, пре свега захваљујући значајним помацима који су учињени на пољу формулације и имплементације различитих мера афирмативне акције у области образовања које су једним делом усмерене и ка припадницима ромске етничке заједнице. Последично, удео Рома без образовања и са незавршеном основном школом ће се постепено смањивати, а број оних са завршеном средњом школом и високим образовањем ће расти што ће значајно изменити образовну структуру ромске популације, као и квалификациону структуру радне снаге унутар те популације. Тиме ће једна важна претпоставка за промену социјалног положаја ромске етничке заједнице на територији Србије бити испуњена. Ипак, само промена образовне и квалификационе структуре није довољна. Јер да би дошло до извесних квалитативних промена и у економској структури ромске популације потребно је уложити додатни напор везан за побољшање актуелних услова на тржишту рада, како би образовани и квалификовани радници Роми били у позицији да се запосле и реализују ове образовне и стручне потенцијале, а то свакако није лак задатак, бар не у данашњој Србији. 
Валентина Соколовска, Исидора Јарић, Образовно-економски статус Рома у Србији и...

\section{ЛИТЕРАТУРА:}

Ball, C. (1990). Politics and Policy Making in Education. London: Routledge.

Вујовић, Сретен (ур.) (2008). Друшӣво ризика: Промене, неједнакостии и социјални йроблеми у данашюој Србији. Београд: Институт за социолошка истраживанја Филозофског факултета у Београду.

Granovetter, M. S. (1973). The strenght of weak ties. The American Journal of Sociology 78(6):

1360-1380.

Đorđević, B. D. J. Živković and D. Todorović (2002). Unemployed Romas (Poll Research). Teme 26(4): 569-595.

Jones, R. \& Thomas, L. (2005). The 2003 UK Government Higher Education White Paper: a critical assessment of its implications for the access and widening participation agenda. Joumal of Education Policy. 20(5): 615-630.

Jones, R. (2002). Restrictive practices: critical reflections on collaboration. Research in Post-Compulsory Education. 7(2):165-176.

Мандић, Ивана (2012). Проблем образовања Рома у Србији. Норма 17(2): 247-245.

Радушки, Нада (2000-2002). Друштвени положај и демографске одлике ромске популације. Срйска йолийичка мисао (1-4): 169-184.

Радушки, Нада (2003). Социо-демографске и етничке особености Рома у Србији. Социолошки ирреілед 37(3-4): 271-284.

Радушки, Нада (2009). Образовање као кључ за интеграцију Рома у друштво. Полиииичка ревија 8(1): 189-202.

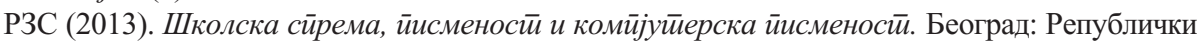
завод за статистику.

РЗС (2014). Основни скуйови стиановнишиевва. Подаџи йо реїионима. Београд: Републички завод за статистику.

Соколовска, Валентина (2011). Социјалне мреже, социјални капитал и друштвени статус. Coциолошки йрейлед 45(2): 221-234.

Sokolovska, Valentina, (2012). Regionalne razlike u Srbiji. U: Sokolovska, Marinković (ur.). Regioni i regionalizacija. Sociološki aspekti. Novi Sad: Mediterran Publishing, str. 137-155.

Taylor, R. (2000). Continuing education practice, lifelong learning and the construction of an accessible higher education in the United Kingdom. Journal of Widening Participation and Lifelong Learning. (2-3): 14-22.

Tight, M. (1998). Education, education, education! The vision of lifelong learning in the Kennedy, Dearing and Fryer Reports. Oxford Review of Education, 24(4): 473-485.

Товиловић, Снежана, Зденка Нововић и Миклош Биро (2009). Ставови према образовању, аспирације и вредности ромских неромских родитеља чија деца полазе у школу. Педа-

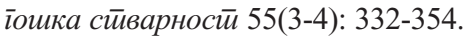

Thomas, E. (2002). Student retention in higher education: the role of institutional habitus. Journal of Education Policy, 17(4): 423-432.

Thompson, J. (2001). Re-rooting lifelong learning. Leicester, UK: National Institute for Adult and Continuing Education.

Freire, P. (1972). Pedagogy of the Oppressed. Harmondsworth, UK: Penguin. 
Valentina Sokolovska

Summary

University of Novi Sad

Faculty of Philosophy

Isidora Jarić

University of Belgrade

Faculty of Philosophy

\section{EDUCATIONAL AND ECONOMIC STATUS OF ROMA IN SERBIA AND ITS REGIONAL DISTRIBUTION}

This paper examines the educational and economic structure of the Roma population in Serbia. The study is based on census data, which are conducted on the territory of the Republic of Serbia in 2002 and 2011. The observed changes in education structure are compared with changes in the economic structure of the Roma population between the two censuses. The authors make an attempt to understand their cause as well as the effect on the future status of the Roma population in Serbia. The paper shows the regional distribution of these two significant demographic structures. The last part of the paper is devoted to the analysis of the means of support and sources of livelihood of the Roma population.

Key words: Roma, educational structure, economic structure, sources of livelihood. 